\title{
Compatibility of entomopathogenic nematodes with insecticides against the cabbage white butterfly, Pieris rapae L. (Lepidoptera: Pieridae)
}

\author{
Ahmed A. A. Aioub ${ }^{1 *} \mathbb{0}$, Ramadan M. El-Ashry' ${ }^{1}$ Ahmed S. Hashem², Ahmed E. Elesawy ${ }^{3}$ and \\ Ahmed E. A. Elsobki ${ }^{1}$
}

\begin{abstract}
Background: Compatibility of entomopathogenic nematodes (EPNs) with insecticides is a crucial mainstay of integrated pest management (IPM) programs. This study was designed to evaluate the joint action of EPN species and insecticides when employed to deter 3rd and 4th larval instars of cabbage white butterfly, Pieris rapae L. (Lepidoptera: Pieridae) under laboratory conditions. EPNs [Steinernema carpocapsae (All strain), S. feltiae (Filipjev), Heterorhabditis bacteriophora (HP88), and H. bacteriophora (Ar-4)], at concentrations of 50, 100, and $125 \mathrm{IJs} / \mathrm{larva}$, were tested with 3 insecticides (lambda-cyhalothrin, emamectin benzoate, and indoxacarb) at $\mathrm{LC}_{25}$ and $\mathrm{LC}_{50}$ values. Additionally, expression profiles of 2 detoxification genes (CYP6AE120 and PrGSTs1) when the 4 th instar larvae were treated by $\mathrm{H}$. bacteriophora (HP88) and lambda-cyhalothrin were examined.

Results: Data indicated that statistically significant mortality of 2 larval instars of $P$. rapae was observed in vitro among EPN species and pesticide concentrations. At concentration of $50 \mathrm{IJs} / \mathrm{larva}, \mathrm{LT}_{50}$ values were 2.385 and 3.92 days for S. carpocapsae (All strain) and H. bacteriophora(Ar-4), respectively, on 3rd instar larvae; also, these values were 3.506 and 3.107 days for S. feltiae and H. bacteriophora (Ar-4), respectively, on 4th instar larvae Lambda-cyhalothrin was the most toxic insecticide, followed by emamectin benzoate and indoxacarb at $\mathrm{LC}_{25}$ and $\mathrm{LC}_{50}$, respectively. An additive effect was observed between EPN species with $L_{25}$ and $L_{50}$ of the tested insecticides, except for lambda-cyhalothrin at $\mathrm{LC}_{50}$ with $\mathrm{H}$. bacteriophora (Ar-4), and indoxacarb, with all EPNs showing antagonistic effects on mortality of 3rd instar larvae after 3 days post-treatment. The interaction between the tested pesticides at $\mathrm{LC}_{25}$ and $\mathrm{LC}_{50}$ and EPN species, showed an additive effect, excluding lambda-cyhalothrin at $\mathrm{LC}_{25}$ with $\mathrm{S}$. carpocapsae (All strain) and $\mathrm{LC}_{25}$ of indoxacarb with $\mathrm{H}$. bacteriophora (Ar-4), which showed potentiation effects. The interaction of S. feltiae (Filipjev) with tested insecticides at $\mathrm{LC}_{50}$ exhibited an antagonistic effect on the mortality of 4 th instar $P$. rapae larvae after 3 days post-treatment. The expression of both CYP6AE120 and PrGSTs1 was significantly up-regulated with lambdacyhalothrin, followed by H. bacteriophora (HP88) compared to control.
\end{abstract}

Conclusions: The findings suggested that combining EPNs and the pesticide concentrations can be a practical strategy for managing P. rapae and could pave the way to using new control technologies in protecting organic farm vegetables from lepidopteran pests.

\footnotetext{
*Correspondence: Ahmedaioub1991@gmail.com; a.aioub@zu.edu.eg

1 Plant Protection Department, Faculty of Agriculture, Zagazig University,

Zagazig 44511, Egypt

Full list of author information is available at the end of the article
}

(c) The Author(s) 2021. Open Access This article is licensed under a Creative Commons Attribution 4.0 International License, which permits use, sharing, adaptation, distribution and reproduction in any medium or format, as long as you give appropriate credit to the original author(s) and the source, provide a link to the Creative Commons licence, and indicate if changes were made. The images or other third party material in this article are included in the article's Creative Commons licence, unless indicated otherwise in a credit line to the material. If material is not included in the article's Creative Commons licence and your intended use is not permitted by statutory regulation or exceeds the permitted use, you will need to obtain permission directly from the copyright holder. To view a copy of this licence, visit http://creativecommons.org/licenses/by/4.0/. 
Keywords: Pieris rapae, Entomopathogenic nematodes, Compatibility, Insecticides, In vitro

\section{Background}

Pieris rapae L. (Lepidoptera: Pieridae), known as cabbage white butterfly, is a major agricultural pest that causes severe losses in crop yields of Brassicaceae worldwide (Kingsolver 2000). P. rapae larvae consume cabbage leaves, reducing them to stalks (Xiang et al. 2018). It also contaminates plants by depositing copious feces on leaves (Reda et al. 2018). However, the widespread use of synthetic pesticides to control the pest not only harmful to the environment, human health, and non-target creatures (Fantke et al. 2012), but also induces resistance in many pests, seriously compromising the effectiveness of the pesticides (Qie et al. 2020). Control of $P$. rapae is becoming increasingly challenging due to its high reproductive capacity, broad temperature tolerance, concealed feeding of the larvae, and failure to succumb to numerous chemical pesticides. Consequently, biological control offers an attractive alternative to traditional insecticides El-Ashry et al. 2021).

Integrated pest management (IPM) can be used to limit the harmful environmental effects of some chemicals, while achieving effective and long-term pest control (Kary et al. 2021). One category of biocontrol agents that appears to be compatible with a wide range of chemical pesticides is entomopathogenic nematodes (EPNs) (Kary et al. 2018).

EPNs from the Steinernematidae and Heterorhabditidae families are fatal a biological control agent that treat a wide range of economically significant insect pests (Laznik and Trdan 2014). EPNs penetrate the insect body and then kill their hosts by releasing symbiotic bacteria during the infective juvenile (IJ) stage (Dara 2017). EPNs can be as effective as chemical insecticides under ideal conditions, including appropriate temperature, humidity, and low UV exposure (Laznik and Trdan 2017). EPNs and other agrochemicals can be used simultaneously or sequentially to control certain pest species or life stages. The use of multiple control agents in combination can improve the efficacy of IPM techniques and provide a cost-effective and time-saving alternative for $P$. rapae management. When two control agents work separately on a target host and the toxicity of one component is unaffected by the other, their combined effects can either be additive, potentiating, or antagonistic (Robertson et al. 2017). Studies suggest that mixing low-impact insecticides or lower insecticide concentrations with biological control agents could improve the biological control agents' effectiveness, while reducing the negative effects of insecticides (El-Ashry and Ramadan 2021). For instance, the mixture of Steinernema carpocapsae and abamectin was used to effectively management of the potato tuber moth, Phthorimaea operculella Zeller (Kary et al. 2021), and Heterorhabditis indica, S. carpocapsae, and indoxacarb were effective together for the control of Spodoptera litura (Fab.) (Khan et al. 2021).

The objectives of this study were to evaluate the compatibility of EPNs and managing the 3rd and 4th larval instars of $P$. rapae under laboratory conditions and examined the expression profile of 2 genes in 4th instar larvae of $P$. rapae in response to different concentrations of EPNs and the tested pesticides.

\section{Methods}

\section{Entomopathogenic nematodes (EPNs)}

Effectiveness of 2 imported steinernematids, S. carpocapsae (All strain) and S. feltiae (Filipjev) as well as 2 heterorhabditids, an imported species $H$. bacteriophora (HP88) and a local species H. bacteriophora (Ar4) isolated formerly from El-Arish district, Egypt by using the modified baiting technique of Galleria mellonella L. (Bedding and Akhurst 1975) were tested on $P$. rapae (Lepidoptera: Pieridae) larvae under laboratory conditions.

\section{Propagation of EPNs}

EPN species used in all experiments were propagated on last instar larvae of G. mellonella. New cultures less than one week old were used and EPNs' cultures were renewed by placing 2 filter papers (Whitman No.1) in a 9-cm Petri dish. Five G. mellonella were placed in each Petri dish and the dish was covered. All EPNs' cultures were held at $25{ }^{\circ} \mathrm{C} \pm 3{ }^{\circ} \mathrm{C}$ for 2 days in the laboratory; dead larvae were transferred to white traps (Kaya and Stock 1997). After 15-20 days, collected EPNs and their suspensions were adjusted to $1000 \mathrm{IJs} / \mathrm{ml}$ and stored in shallow distilled water in transfer flasks at $12{ }^{\circ} \mathrm{C}$ for up to 7 days prior to use.

\section{Source of insects}

Third and 4th larval instars of $P$. rapae were collected from cabbage fields in the Zagazig district, Sharqia Governorate, Egypt in March 2021. Larvae were placed in wooden cages $(25 \times 20 \times 18 \mathrm{~cm})$ containing leaves of local cabbage from the collection sites (Brassica oleraceae, Cruciferaceae) as a food source, and held in the laboratory at $25 \pm 3{ }^{\circ} \mathrm{C}$. Fresh leaves were provided regularly ad libitum; the developing larvae shifted from old to fresh leaves independently. 


\section{Tested pesticides}

$\mathrm{LC}_{25}$ and $\mathrm{LC}_{50}$ of emamectin benzoate (avermectin insecticide, known commercially as Exellent, 1.9\% EC, Kafr El Zayat Pesticides and Chemical Company, Egypt), indoxacarb (oxadiazine insecticide, known commercially as Avaunt, 15\% EC, DuPont, USA) and lambda-cyhalothrin (pyrethroid insecticide, known commercially as lambda $10 \%$ EC, DuPont, USA) for concentrations of $0.25,0.5,1$, 2, 4, 8 and 16 ppm were tested against 3rd and 4th larval instars of $P$. rapae.

\section{Virulence of EPNs with P. rapae larvae}

Comparative infectivity of imported nematodes and local isolate $\mathrm{Ar}-4$ of $\mathrm{H}$. bacteriophora was measured under laboratory conditions $\left(25 \pm 3{ }^{\circ} \mathrm{C}\right)$ using Petri dish assays on 3rd and 4th larval instars. A 9-cm Petri dish lined with 2 filter papers (Whitman No.1) and approximately 50, 100 or 125 IJs/larva was used in $0.5 \mathrm{ml}$ and each dish was seeded with 5 healthy 3 rd or 4 th instars of $P$. rapae larvae. Control Petri dishes received only distilled water. Each treatment was replicated 5 times and $P$. rapae mortality rate was recorded daily for 5 days. The percentage of mortality and median lethal time $\left(\mathrm{LT}_{50}\right)$ of nematodes were estimated. Dead larvae after one, two, three, four, and five days were observed and transferred to the white trap. Dead larvae were examined, using a dissecting microscope for the presence of tested EPN species. Percentage of mortality was calculated according to the following equation:

$$
\begin{aligned}
\text { Mortality }(\%)= & (\text { Number of dead larvae }) / \\
& (\text { Total number of larvae }) \times 100
\end{aligned}
$$

\section{Bioassay of tested insecticides with $P$. rapae larvae}

Emamectin benzoate, indoxacarb, and lambda-cyhalothrin were tested against 3rd and 4th larval instars of $P$. rapae in Petri dish assays. The effectiveness of each pesticide at concentrations of $\mathrm{LC}_{25}$ and $\mathrm{LC}_{50}$ was estimated. Each Petri dish was lined with 2 pieces of filter paper (Whitman No.1) and 5 healthy 3rd or 4th larval instars were introduced. Immediately, 2 discs (5-cm diameter) of local cabbage immersed in $\mathrm{LC}_{25}$ and $\mathrm{LC}_{50}$ of each insecticide concentration for one $\mathrm{min}$ and air-dried for $3 \mathrm{~min}$ were introduced to 3 rd or 4th larval instars. Control Petri dishes received only 2 fresh cabbage discs washed in distilled water. As mentioned before, each treatment was replicated 5 times and $P$. rapae mortality percentage was recorded daily for 5 days.

\section{Combine effect of a low EPNs' concentration with tested insecticides on $P$. rapae larvae}

Combined effect of lambda-cyhalothrin, emamectin benzoate, and indoxacarb and 50 IJs/larva of tested EPNs on 3rd and 4th larval instars were investigated. Five active larvae (3rd or 4th instars) were placed in each Petri dish (9-cm diameter) lined with moist filter paper and provided with 2 discs of cabbage leaves (5-cm diameter) rinsed in $\mathrm{LC}_{25}$ and $\mathrm{LC}_{50}$ of emamectin benzoate, indoxacarb and lambda-cyhalothrin for one min and left to air-dry for $3 \mathrm{~min}$. These were sprayed by $0.5 \mathrm{ml}$ of EPN suspension containing $50 \mathrm{IJs} /$ larva. Petri dishes were immediately sealed tight and were incubated under laboratory conditions at $25 \pm 3{ }^{\circ} \mathrm{C}$. Control Petri dishes contained only 5 larvae for each instar provided with 2 fresh cabbage discs washed in distilled water. Each instar (3rd or 4th) of larvae treated with $\mathrm{LC}_{25}$ and $\mathrm{LC}_{50}$ of insecticides and EPNs was replicated 5 times and $P$. rapae mortality percentage was recorded daily for 5 days.

The joint action of the EPNs and pesticides was estimated according to Richer's (1987) formula:

$$
E=(X+Y)-X Y / 100
$$

where $E=$ expected effect of the combination and $X$ and $Y=$ mortality percentages resulting from $X$ and $Y$, respectively.

The expected effect was compared to the actual effect obtained experimentally from the insecticide interaction mixture according to Mansour et al. (1966):

$$
\begin{aligned}
& \text { Co - toxicity Factor } \\
& \qquad=\frac{\text { Observed effect }(\%)-\text { Expected effect }(\%)}{\text { Expected effect }(\%)} \times 100
\end{aligned}
$$

Three categories were used to classify the co-toxicity factor effect. A co-toxicity factor $\geq+20$ was considered potentiation, while $\leq-20$ was considered as antagonism and -20 to +20 indicated an additive effect.

\section{Gene expression}

Expression profiles of 2 genes (CYP6AE120 belonging to Cytochrome P-450 and PrGSTs1 belonging to glutathione S-transferase) were determined according to Liu et al. (2018). These were investigated by RT-qPCR in different concentrations of the 2 best treatments $(H$. bacteriophora (HP88) and lambda-cyhalothrin) for controlling 4th instar larvae of $P$. rapae.

\section{RNA extraction}

RT-qPCR was used to investigate the expression profiles of CYP6AE120 and PrGSTs. RNA extraction from tissue samples was conducted using QIAamp RNeasy Mini kit (Qiagen, Germany, GmbH) when $30 \mathrm{mg}$ of the sample was added to $600 \mu \mathrm{l}$ RLT buffer containing $10 \mu \mathrm{l}$ $\beta$-mercaptoethanol per $1 \mathrm{ml}$. For homogenization of samples, tubes were placed into adaptor sets, which were 


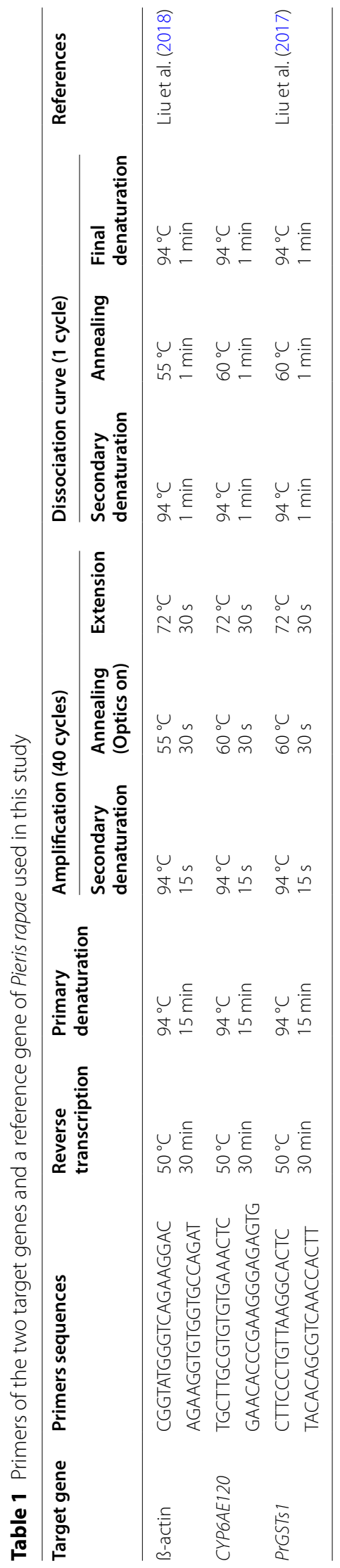


fixed into the clamps of a Qiagen tissue Lyser. Disruption was performed in a two-minute high-speed $(30 \mathrm{~Hz})$ shaking step. One volume of $70 \%$ ethanol was added to the cleared lysate, and the steps were completed according to the "purification of total RNA from animal tissues" protocol of the QIAamp RNeasy Mini kit (Qiagen, Germany, GmbH). One column DNase digestion was done to remove residual DNA. Primers were used in a $25-\mu \mathrm{l}$ reaction containing $12.5 \mu \mathrm{l}$ of the $2 \times$ QuantiTect SYBR Green PCR Master Mix (Qiagen, Germany, GmbH), $0.25 \mu \mathrm{l}$ of RevertAid Reverse Transcriptase $(200 \mathrm{U} / \mu \mathrm{L})$ (Thermo Fisher), $0.5 \mu \mathrm{l}$ of each primer of $20 \mathrm{pmol}$ concentration, $8.25 \mu \mathrm{l}$ of water, and $3 \mu \mathrm{l}$ of RNA template. Primers for RT-qPCR are listed in Table 1 . The housekeeping gene $(\beta$-actin) was used as an internal reference to normalize target gene expression. The reaction was performed in a Stratagene MX3005P real-time PCR machine. The relative quantification of gene expression was computed using the $2^{-\Delta \Delta C t}$ method (Yuan et al. 2006).

\section{Statistical analysis}

A complete randomized design was implemented in all experiments. Data were analyzed using ANOVA with CoStat version 6.45. Means were compared via Tukey's multiple range tests at $P \leq 0.05$ probabilities. The median lethal time $\left(\mathrm{LT}_{50}\right)$ and median lethal concentrate $\left(\mathrm{LC}_{50}\right)$ values were calculated by probit analysis (Finney 1971) using AnalystSoft Biostat Pro V 5.8.4.3 software.

\section{Results}

\section{Pathogenicity of different EPNs' concentrations to 3rd and 4th larval instars of $P$. rapae under laboratory conditions}

At low EPNs' concentrations (50 IJs/larvae), efficacy of tested Steinernematidae and Heterorhabditidae species varied according to species and days after treatment. The highest mortality values in 3rd instar larvae were detected by $H$. bacteriophora (HP88) and S. carpocapsae (All strain) at the concentration of $50 \mathrm{IJs} /$ larva after 2-3 days post-treatment (H. bacteriophora (HP88) 2 days (28\%), 3 days (60\%); S. carpocapsae (All strain) 2 days (24\%), 3 days (52\%)). At 4 days after treatment, the highest mortality values were observed in Petri dishes treated with H. bacteriophora (HP88), followed by local EPN species $H$. bacteriophora (Ar-4) with percent mortality (88 and $76 \%$ ), respectively, reaching (100\%), 5 days post-treatment (Table 2). Imported H. bacteriophora (HP88) and local H. bacteriophora (Ar-4) displayed the highest virulence in 4 th instar $P$. rapae larvae with percent of mortality (28\%) (HP88, 2 days; (64\%), 3 days; Ar-4, 2 days, (24\%); 3 days, (48\%), followed by S. carpocapsae (All strain) with percent mortality (16\%), 2 days and (48), 3 days. The lowest mortality value was observed by $S$. feltiae
(Filipjev) with 3rd and 4th larval instars of $P$. rapae in all treatment periods (Table 3).

At a concentration of $100 \mathrm{IJs} /$ larva, the numbers of dead larvae were clearly increased at different times of exposure. For instance, the percentage of dead instars in Petri dishes of $H$. bacteriophora (HP88) after 3-4 days of exposure were (68 and 92\%), respectively and for $H$. bacteriophora (Ar-4) (52 and 88\%), respectively and reached (100\%), 5 days post-treatment. The lowest percentage of mortality (72\%) was detected with S. feltiae (Filipjev) after 4 days of treatment (Table 2). The percentage of mortality of the 4th instar $P$. rapae larvae significantly increased $(p \leq 0.05)$ and achieved (96\%) by H. bacteriophora (HP88) and (92\%) by H. bacteriophora (Ar-4). Mortality recorded by $S$. carpocapsae (All strain) was $(76.00 \%)$ and $(68 \%)$ by S. feltiae (Filipjev) after 4 days of treatments (Table 3). Also, mortality percentage of the first 3 species of EPNs reached (100\%) five days post-treatment.

Table 2 shows the efficacy of high concentrations (125 IJs/larva) of tested EPN species with 3rd and 4th larval instars of $P$. rapae. Petri dishes treated with $H$. bacteriophora (HP88) reached (72 and 100\%) 3 and 4 days posttreatment, respectively, whereas they reached (72 and 92\%) with H. bacteriophora (Ar-4) after the same periods of time, respectively, against the $3 \mathrm{rd}$ instar larvae of $P$. rapae. On the other hand, pathogenicity of tested EPN species reached (84\%) with H. bacteriophora (HP88), (76\%) with H. bacteriophora (Ar-4) and (60\%) with S. carpocapsae (All strain) after 3 days post-treatment. H. bacteriophora (HP88), followed by $H$. bacteriophora (Ar-4) displayed a great virulence in the 4th instar of $P$. rapae with (100 and 96\%) mortality, respectively after 4 days of treatment (Table 3).

As shown in Table 4, H. bacteriophora (Ar-4) (All strain) was the most virulent nematode species with the 3rd and 4th larval instars with $\mathrm{LT}_{50}$ values of 3.292 and 3.107 days, respectively. While this value was 2.763 days by $S$. carpocapsae (All strain) with the 3rd instar larvae.. Conversely, S. feltiae was less virulent to the 4th instar larvae with $\mathrm{LT}_{50}$ value of 3.506 days.

\section{Toxicity of tested pesticides to the 3rd and 4th larval instars of $P$. rapae}

The respect $\mathrm{LC}_{25}$ and $\mathrm{LC}_{50}$ values were (1.52 and $2.48 \mathrm{ppm})$ for lambda-cyhalothrin, (2.30 and $4.82 \mathrm{ppm})$ for emamectin benzoate and (3.12 and $6.31 \mathrm{ppm})$ for indoxacarb at 3 days post treatment for the 3rd instar $P$. rapae larvae. Whereas for the 4 th instar $P$. rapae larvae, the respect of these values were (1.92 and $3.58 \mathrm{ppm})$ for lambda-cyhalothrin, (2.88 and $5.16 \mathrm{ppm}$ ) for emamectin benzoate and ( 3.67 and $6.97 \mathrm{ppm}$ ) for indoxacarb at 3 days post treatment.

The 3rd and 4th larval instars of $P$. rapae displayed different mortality percentages and $\mathrm{LT}_{50}$ values after treatment 
Table 2 Efficacy of EPN species at concentrations of 50, 100 and $125 \mathrm{JJ} /$ /arva against the 3rd instar larvae of Pieris rapae after different time intervals

\begin{tabular}{|c|c|c|c|c|c|}
\hline \multirow[t]{2}{*}{ Treatments } & \multicolumn{5}{|c|}{$\%$ Mortality of 3rd instar Pieris rapae larvae at time intervals post treatments } \\
\hline & One day & Two days & Three days & Four days & Five days \\
\hline & \multicolumn{5}{|c|}{$50 \mathrm{IJs} / \mathrm{larva}$} \\
\hline Steinernema Hecarpocapsae (All strain) & $4.00 \mathrm{a}$ & $24.00 \mathrm{ab}$ & $52.00 \mathrm{ab}$ & $72.00 \mathrm{~b}$ & $96.00 \mathrm{ab}$ \\
\hline S. feltiae (Filipjev) & 0.00 & $16.00 \mathrm{~b}$ & $44.00 \mathrm{~b}$ & $64.00 \mathrm{~b}$ & $88.00 \mathrm{~b}$ \\
\hline Heterorhabditis bacteriophora (HP88) & $8.00 \mathrm{a}$ & $28.00 \mathrm{a}$ & $60.00 \mathrm{a}$ & $88.00 \mathrm{a}$ & $100.00 \mathrm{a}$ \\
\hline \multirow[t]{2}{*}{ H.bacteriophora (Ar-4) } & 0.00 & $20.00 a b$ & $44.00 \mathrm{~b}$ & $76.00 \mathrm{ab}$ & $100.00 \mathrm{a}$ \\
\hline & \multicolumn{5}{|c|}{$100 \mathrm{IJs} / \mathrm{larva}$} \\
\hline S.carpocapsae (All strain) & $8.00 \mathrm{a}$ & $24.00 \mathrm{ab}$ & $52.00 \mathrm{~b}$ & $80.00 \mathrm{ab}$ & $96.00 \mathrm{a}$ \\
\hline S. feltiae (Filipjev) & $8.00 \mathrm{a}$ & $16.00 \mathrm{~b}$ & $52.00 \mathrm{~b}$ & $72.00 \mathrm{~b}$ & $92.00 \mathrm{a}$ \\
\hline H.bacteriophora (HP88) & $16.00 \mathrm{a}$ & $28.00 \mathrm{ab}$ & $68.00 \mathrm{a}$ & $92.00 \mathrm{a}$ & $100.00 \mathrm{a}$ \\
\hline \multirow[t]{2}{*}{ H.bacteriophora (Ar-4) } & $12.00 \mathrm{a}$ & $32.00 \mathrm{a}$ & $68.00 \mathrm{a}$ & $88.00 \mathrm{a}$ & $100.00 \mathrm{a}$ \\
\hline & \multicolumn{5}{|c|}{$125 \mathrm{IJs} / \mathrm{larva}$} \\
\hline S.carpocapsae (All strain) & $12.00 \mathrm{a}$ & $28.00 \mathrm{a}$ & $56.00 \mathrm{~b}$ & $88.00 \mathrm{ab}$ & $96.00 \mathrm{a}$ \\
\hline S. feltiae (Filipjev) & $8.00 \mathrm{a}$ & $24.00 \mathrm{a}$ & $56.00 \mathrm{~b}$ & $76.00 \mathrm{~b}$ & $92.00 \mathrm{a}$ \\
\hline H.bacteriophora (HP88) & $20.00 \mathrm{a}$ & $36.00 \mathrm{a}$ & $72.00 \mathrm{a}$ & $100.00 \mathrm{a}$ & $100.00 \mathrm{a}$ \\
\hline H.bacteriophora (Ar-4) & $16.00 \mathrm{a}$ & $36.00 \mathrm{a}$ & $72.00 \mathrm{a}$ & $92.00 \mathrm{a}$ & $100.00 \mathrm{a}$ \\
\hline
\end{tabular}

Reported numbers represent means of 5 replicates

Different letter(s) in the same column represent significant differences $(P \leq 0.05)$ according to Tukey`s multiple range test

Mortality $(\%)=\frac{\text { Number of dead larvae }}{\text { Total number of larvae }} \times 100$

Table 3 Efficacy of EPN species at concentrations of 50, 100 and $125 \mathrm{IJ} /$ /larva against the 4rd instar Pieris rapae larvae after different time intervals

\begin{tabular}{|c|c|c|c|c|c|}
\hline \multirow[t]{2}{*}{ Treatments } & \multicolumn{5}{|l|}{$\begin{array}{l}\text { \% Mortality of 4th instar Pieris rapae } \\
\text { larvae at time intervals post treatments }\end{array}$} \\
\hline & One day & Two days & Three days & Four days & Five days \\
\hline & $50 \mathrm{IJs} / \mathrm{larva}$ & & & & \\
\hline Steinernema carpocapsae (All strain) & $4.00 \mathrm{ab}$ & $16.00 \mathrm{ab}$ & $48.00 \mathrm{~b}$ & $68.00 c$ & $92.00 \mathrm{ab}$ \\
\hline S. feltiae (Filipjev) & $0.00 \mathrm{~b}$ & $12.00 \mathrm{~b}$ & $40.00 \mathrm{~b}$ & $60.00 c$ & 84.00 b \\
\hline Heterorhabditis bacteriophora (HP88) & $12.00 \mathrm{a}$ & $28.00 \mathrm{a}$ & $64.00 \mathrm{a}$ & $92.00 \mathrm{a}$ & $100.00 \mathrm{a}$ \\
\hline \multirow[t]{2}{*}{ H.bacteriophora (Ar-4) } & $8.00 \mathrm{ab}$ & $24.00 \mathrm{ab}$ & $48.00 \mathrm{~b}$ & $80.00 \mathrm{~b}$ & $100.00 \mathrm{a}$ \\
\hline & $100 \mathrm{IJs} / \mathrm{larva}$ & & & & \\
\hline S.carpocapsae (All strain) & $8.00 \mathrm{~b}$ & $20.00 \mathrm{~b}$ & $56.00 \mathrm{bc}$ & $76.00 \mathrm{~b}$ & $100.00 \mathrm{a}$ \\
\hline S. feltiae (Filipjev) & $4.00 \mathrm{~b}$ & $16.00 \mathrm{~b}$ & $48.00 \mathrm{c}$ & $68.00 \mathrm{~b}$ & $88.00 \mathrm{~b}$ \\
\hline H.bacteriophora (HP88) & $20.00 \mathrm{a}$ & $40.00 \mathrm{a}$ & $72.00 \mathrm{a}$ & $96.00 \mathrm{a}$ & $100.00 \mathrm{a}$ \\
\hline \multirow[t]{2}{*}{ H.bacteriophora (Ar-4) } & $20.00 \mathrm{a}$ & $36.00 \mathrm{a}$ & $68.00 a b$ & $92.00 \mathrm{a}$ & $100.00 \mathrm{a}$ \\
\hline & $125 \mathrm{IJs} / \mathrm{larva}$ & & & & \\
\hline S.carpocapsae (All strain) & $16.00 \mathrm{ab}$ & $32.00 \mathrm{bc}$ & $60.00 \mathrm{~b}$ & $80.00 \mathrm{~b}$ & $100.00 \mathrm{a}$ \\
\hline S. feltiae (Filipjev) & $12.00 \mathrm{~b}$ & $24.00 \mathrm{c}$ & $60.00 \mathrm{~b}$ & $76.00 \mathrm{~b}$ & $96.00 \mathrm{a}$ \\
\hline H.bacteriophora (HP88) & $24.00 \mathrm{a}$ & $48.00 \mathrm{a}$ & $84.00 \mathrm{a}$ & $100.00 \mathrm{a}$ & $100.00 \mathrm{a}$ \\
\hline H.bacteriophora (Ar-4) & $20.00 a b$ & $40.00 \mathrm{ab}$ & $76.00 \mathrm{a}$ & $96.00 \mathrm{a}$ & $100.00 \mathrm{a}$ \\
\hline
\end{tabular}

Reported numbers represent means of 5 replicates

Different letter(s) in the same column represent significant differences $(P \leq 0.05)$ according to Tykey`s multiple range test

Mortality $(\%)=\frac{\text { Number of dead larvae }}{\text { Total number of larvae }} \times 100$ 
Table 4 Median lethal time $\left(L T_{50}\right)$ values of Steinernema carpocapsae (All strain) and S. feltiae (Filipjev), Heterorhabditis bacteriophora (HP88) and H. bacteriophora (Ar-4) against 3rd and 4th instar larvae of cabbageworm, Pieris rapae at a concentration of $50 \mathrm{lJs} / \mathrm{larva}$

\begin{tabular}{lllll}
\hline $\begin{array}{l}\text { Used } \\
\text { concentration instars }\end{array}$ & $\begin{array}{l}\text { P.rapae } \\
\text { carpocapsae } \\
\text { (All strain) } \\
\mathrm{LT}_{\mathbf{5 0}} \text { (days) }\end{array}$ & $\begin{array}{l}\text { S.feltiae } \\
\text { (Filipjev) }\end{array}$ & $\begin{array}{l}\text { H. } \\
\text { bacteriophora } \\
\text { (HP88) }\end{array}$ & $\begin{array}{l}\text { H.bacteriophora } \\
\text { (Ar-4) }\end{array}$ \\
\hline $50 \mathrm{lJs} /$ larva & 3rd instar 2.763 & - & - & 3.292 \\
& 4th instar - & 3.506 & - & 3.107 \\
\hline
\end{tabular}

The $\mathrm{LT}_{50}$ values express median lethal time

with $\mathrm{LC}_{25}$ and $\mathrm{LC}_{50}$ values of lambda-cyhalothrin emamectin benzoate and indoxacarb (Tables 5, 6 and 7). The present results indicated that the mortally of 3rd instar larvae achieved by lambda-cyhalothrin was (48 and 80\%) 3 days post-treatment with $\mathrm{LC}_{25}$ and $\mathrm{LC}_{50}$, respectively. Parallel values with emamectin benzoate were (36 and $60 \%$ ) and with indoxacarb (24 and 52\%) at $\mathrm{LC}_{25}$ and $\mathrm{LC}_{50}$, respectively (Table 5 ). The mortality of 4 th instar larvae 3 days post-treatment at $\mathrm{LC}_{25}$ and $\mathrm{LC}_{50}$ were (40 and 80\%) with lambda-cyhalothrin, (28 and 56\%) with emamectin benzoate and (48 and 20\%) with indoxacarb (Table 6).

As shown to Table $7, \mathrm{LT}_{50}$ value of 3.344 days at $\mathrm{LC}_{25}$ of lambda-cyhalothrin revealed the most virulent pesticide on 3rd instar larvae, while for emamectin benzoate this value was 3.84 days on the 4th instar larvae. $\mathrm{LT}_{50}$ values of indoxacarb were 4.22 and 4.12 days for 3rd and 4th larval instars, respectively. On the other hand, emamectin benzoate at $\mathrm{LC}_{50}$ was the most virulent pesticide with $\mathrm{LT}_{50}$ values of 2.61 and 2.74 for 3rd and 4th larval instars, respectively. Indoxacarb at $\mathrm{LC}_{50}$ was the least virulent

Table 5 Efficacy of emamectin benzoate, lambda-cyhalothrin and indoxacarb at $\mathrm{LC}_{25}$ and $\mathrm{LC}_{50}$ values against $P$. rapae 3 rd instar larvae after different time intervals

\begin{tabular}{|c|c|c|c|c|c|}
\hline \multirow[t]{2}{*}{ Treatments } & \multicolumn{5}{|c|}{$\%$ Mortality of 3rd instar Pieris rapae larvae at time intervals post treatments } \\
\hline & One day & Two days & Three days & Four days & Five days \\
\hline & $\mathrm{LC}_{25}$ & & & & \\
\hline Lambda-cyhalothrin & $4.00 \mathrm{ab}$ & $20.00 \mathrm{~b}$ & $48.00 \mathrm{bc}$ & $80.00 \mathrm{~b}$ & $96.00 \mathrm{ab}$ \\
\hline Emamectin benzoate & $4.00 \mathrm{ab}$ & $16.00 \mathrm{bc}$ & $36.00 \mathrm{~cd}$ & $64.00 \mathrm{c}$ & $88.00 \mathrm{bc}$ \\
\hline \multirow[t]{2}{*}{ Indoxacarb } & $0.00 \mathrm{~b}$ & $8.00 \mathrm{c}$ & $24.00 \mathrm{~d}$ & $44.00 \mathrm{~d}$ & $64.00 \mathrm{~d}$ \\
\hline & $\mathrm{LC}_{50}$ & & & & \\
\hline Lambda-cyhalothrin & $12.00 \mathrm{a}$ & $32.00 \mathrm{a}$ & $80.00 \mathrm{a}$ & $100.00 \mathrm{a}$ & $100.00 \mathrm{a}$ \\
\hline Emamectin benzoate & $4.00 \mathrm{ab}$ & $24.00 \mathrm{ab}$ & $60.00 \mathrm{~b}$ & $76.00 \mathrm{bc}$ & $92.00 a b c$ \\
\hline Indoxacarb & $4.00 a b$ & $20.00 \mathrm{~b}$ & $52.00 \mathrm{~b}$ & $68.00 \mathrm{bc}$ & $84.00 \mathrm{C}$ \\
\hline
\end{tabular}

Reported numbers represent means of 5 replicates

Different letter(s) in the same column represent significant differences $(P \leq 0.05)$ according to Tukey`s multiple range test

Mortality $(\%)=\frac{\text { Number of dead larvae }}{\text { Total number of larvae }} \times 100$

Table 6 Efficacy of emamectin benzoate, lambda-cyhalothrin and indoxacarb at $L C_{25}$ and $L C_{50}$ values against $P$. rapae 4 rd instar larvae after different time intervals

\begin{tabular}{|c|c|c|c|c|c|}
\hline \multirow[t]{2}{*}{ Treatments } & \multicolumn{5}{|c|}{$\%$ Mortality of 4th instar Pieris rapae larvae at time intervals post treatments } \\
\hline & One day & Two days & Three days & Four days & Five days \\
\hline & $\mathrm{LC}_{25}$ & & & & \\
\hline Lambda-cyhalothrin & $4.00 \mathrm{~b}$ & $16.00 \mathrm{bc}$ & $40.00 \mathrm{C}$ & $60.00 \mathrm{bc}$ & $92.00 \mathrm{ab}$ \\
\hline Emamectin benzoate & $4.00 \mathrm{~b}$ & $12.00 \mathrm{bc}$ & $28.00 \mathrm{~d}$ & $56.00 \mathrm{C}$ & $84.00 \mathrm{bc}$ \\
\hline \multirow[t]{2}{*}{ Indoxacarb } & $4.00 \mathrm{~b}$ & $8.00 \mathrm{C}$ & $20.00 \mathrm{~d}$ & $44.00 \mathrm{~d}$ & $68.00 \mathrm{~d}$ \\
\hline & $\mathrm{LC}_{50}$ & & & & \\
\hline Lambda-cyhalothrin & $16.00 \mathrm{a}$ & $36.00 \mathrm{a}$ & $80.00 \mathrm{a}$ & $100.00 \mathrm{a}$ & $100.00 \mathrm{a}$ \\
\hline Emamectin benzoate & $4.00 \mathrm{~b}$ & $20.00 \mathrm{~b}$ & $56.00 \mathrm{~b}$ & $68.00 \mathrm{~b}$ & $88.00 b c$ \\
\hline Indoxacarb & $4.00 \mathrm{~b}$ & $16.00 \mathrm{bc}$ & $48.00 \mathrm{bc}$ & $68.00 \mathrm{~b}$ & $80.00 \mathrm{c}$ \\
\hline
\end{tabular}

Reported numbers represent means of 5 replicates

Different letter(s) in the same column represent significant differences $(P \leq 0.05)$ according to Tukey`s multiple range test

Mortality $(\%)=\frac{\text { Number of dead larvae }}{\text { Total number of larvae }} \times 100$ 
Table 7 Median lethal time $\left(L T_{50}\right)$ values of lambda-cyhalothrin, emamectin benzoate and indoxacarb at $\mathrm{LC}_{25}$ and $\mathrm{LC}_{50}$ against $3 r d$ and 4th larval instars of cabbageworm, Prapae

\begin{tabular}{llcll}
\hline \multirow{2}{*}{$\begin{array}{l}\text { Used } \\
\text { concentrations }\end{array}$} & \multicolumn{2}{l}{ P.rapae instars } & $\mathbf{L T}_{\mathbf{5 0}}$ (Days) \\
\cline { 3 - 5 } & & $\begin{array}{l}\text { Lambda- } \\
\text { cyhalothrin }\end{array}$ & $\begin{array}{l}\text { Emamectin } \\
\text { benzoate }\end{array}$ \\
\hline $\mathrm{LC}_{25}$ & 3rd instar & 3.34 & - & 4.22 \\
& 4th instar & - & 3.84 & 4.12 \\
$\mathrm{LC}_{50}$ & 3rd instar & - & 2.61 & 2.90 \\
& 4th instar & - & 2.74 & 3.12 \\
\hline
\end{tabular}

The $\mathrm{LT}_{50}$ values express median lethal time

pesticide with $\mathrm{LT}_{50}$ values of 2.90 and 3.12 days for 3rd and 4th larval instars, respectively.

\section{Interactions between EPN species ( $50 \mathrm{IJs} / \mathrm{larva}$ ) and LC25 and LC50 of tested pesticides on 3rd and 4th larval instars' mortality}

As shown in Fig. 1a, an additive effect after 3 days of application was observed among the EPN species $S$. carpocapsae (All strain), S. feltiae, H. bacteriophora (HP88) and $H$. bacteriophora (Ar-4) on 3rd instar larvae of $P$. rapae at the concentrations of $50 \mathrm{IJs} /$ larva and $\mathrm{LC}_{25}$ of lambda-cyhalothrin. Co-toxicity factors (CF) were -4.05 (S. carpocapsae (All strain)),-9.71 (S. feltiae), -14.14 (H. bacteriophora (HP88)) and -15.35 (H. bacteriophora (Ar-4)). Similarly, CF were 6.81, 6.48,-13.98,-3.37, for emamectin benzoate with $S$. carpocapsae (All strain), $S$. feltiae, H. bacteriophora (HP88) and H. bacteriophora (Ar-4), respectively, and for indoxacarb these values were -14.99 for $S$. carpocapsae (All strain), -16.43 for $S$. feltiae, -10.92 for H. bacteriophora (HP88) and 4.46 for H. bacteriophora (Ar-4).

Application of lambda-cyhalothrin at $\mathrm{LC}_{50}$ value and EPN species [(S. carpocapsae (All strain), S. feltiae, $H$. bacteriophora (HP88)] on 3rd instar larvae of P. rapae produced an additive effect with CFs $-15.93,-18.92$, and -15.22 , respectively, while an antagonistic effect was observed only with $H$. bacteriophora (Ar-4) at a concentration of $50 \mathrm{IJs} /$ larva with $\mathrm{CF}-30.18$. The interaction between emamectin benzoate at $\mathrm{LC}_{50}$ and tested $\mathrm{EPN}$ species [(S. carpocapsae (All strain), S. feltiae, H. bacteriophora (HP88) and H. bacteriophora (Ar-4)] exhibited an additive effect with $\mathrm{CF}-8.42,-12.37,-14.29$, and -7.22 , respectively. On the other hand, an antagonistic effect was observed in treatments of $\mathrm{LC}_{50}$

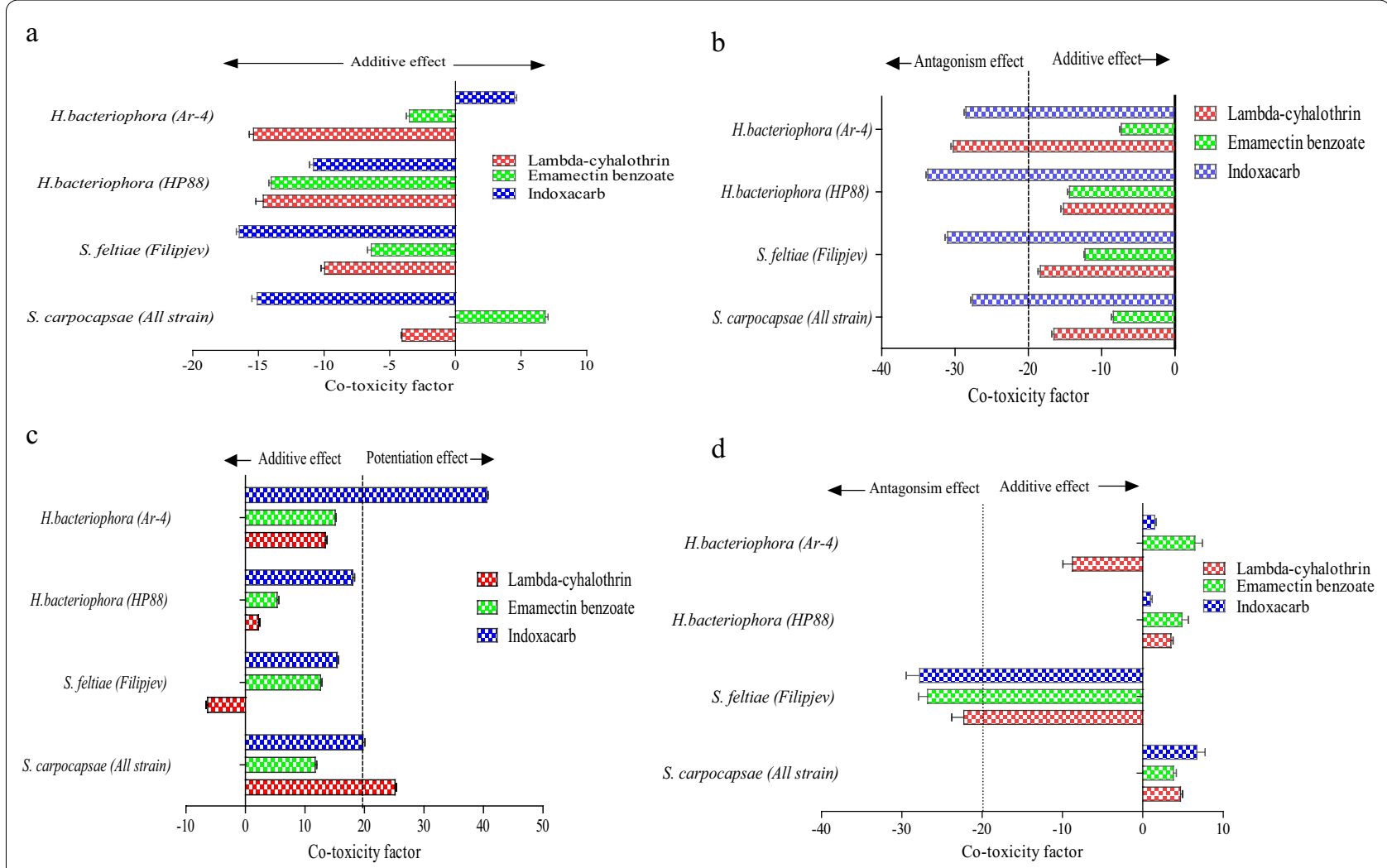

Fig. 1 Interactions between $\mathrm{LC}_{25}(\mathbf{a}, \mathbf{c})$ and $\mathrm{LC}_{50}(\mathbf{b}$, d $)$ values of insecticides with $50 \mathrm{IJs} /$ larvae of EPNs after 3 days post treatment on mortality of the 3 rd $(\mathbf{a}, \mathbf{b})$ and 4 th $(\mathbf{c}, \mathbf{d})$ instar larvae of P. rapae under laboratory conditions 
of indoxacarb and $S$. carpocapsae (All strain) with CF - 27.23, S. feltiae with CF - 31.62, H. bacteriophora (HP88) with CF -33.17 and H. bacteriophora (Ar-4) with CF -28.88 (Fig. 1b).

Effects of the combinations between EPNs and $\mathrm{LC}_{25}$ of pesticides on the 4th instar $P$. rapae larvae are shown in Fig. 1c. A potentiation effect was observed only with $\mathrm{LC}_{25}$ lambda-cyhalothrin and indoxacarb with $S$. carpocapsae (All strain) and H. bacteriophora (Ar-4) with CF 25.00 and 40.41, respectively. Mortality rates increased from (40\%) with $\mathrm{LC}_{25}$ of lambda-cyhalothrin to $(60,80$, and 78\%) when combined with S. feltiae, H. bacteriophora (HP88) and H. bacteriophora (Ar-4), respectively and caused additive effects with CF $-6.25,2.04$ and 13.37. An additive effect was observed by the interaction of emamectin benzoate at $\mathrm{LC}_{25}$ and $S$. carpocapsae (All strain) with CF 11.89, S. feltiae with CF 12.68, H. bacteriophora (HP88) with CF 5.29 and H. bacteriophora (Ar-4) with CF 15.09. CF values achieved in combination treatments between indoxacarb at $\mathrm{LC}_{25}$ and $S$. carpocapsae (All strain), S. feltiae and H. bacteriophora (HP88) were 19.86, 15.38 , and 17.98 , respectively.

Figure 1d illustrates an antagonistic effect on 4th instar P. rapae larvae from the combination of $\mathrm{LC}_{50}$ of lambdacyhalothrin, emamectin benzoate, and indoxacarb with $S$. feltiae with $\mathrm{CF}-22.73,-26.63$, and -27.33 , respectively. The interaction between $\mathrm{LC}_{50}$ of lambda-cyhalothrin and S. carpocapsae (All strain), H. bacteriophora (HP88) and $H$. bacteriophora (Ar-4) achieved additive effects with CF values of $4.91,3.45$, and -8.48 , respectively. CF 3.73 was observed between emamectin benzoate at $\mathrm{LC}_{50}$ and S. carpocapsae (All strain), followed by $H$. bacteriophora (HP88) with CF 4.56 and then H. bacteriophora (Ar-4) with CF 6.33 and achieved an additive effect. Likewise, an additive effect was observed from the interaction of $\mathrm{LC}_{50}$ of indoxacarb and $S$. carpocapsae (All strain) with CF 6.961, H. bacteriophora (HP88) with CF 0.89 and $H$. bacteriophora (Ar-4) with CF 1.43.

\section{Expression of PrGSTs1 and CYP6AE120 in larvae exposed to H. bacteriophora (HP88) and lambda-cyhalothrin}

The expression of CYP6AE120 and PrGSTs1 was investigated using $H$. bacteriophora (HP88) at 50,100,125 IJs/ larva and lambda-cyhalothrin at $\mathrm{LC}_{25}$ and $\mathrm{LC}_{50}$ values to control the 4th instar larvae of $P$. rapae, respectively (Fig. 2). The result revealed that the expression of CYP6AE120 and PrGSTs1 was significantly up-regulated at all concentrations of $H$. bacteriophora (HP88) and lambda-cyhalothrin than the control. Moreover, the expression of the 2 tested genes caused significant changes in 4th instar larvae of $P$. rapae with lambdacyhalothrin than H. bacteriophora (HP88).
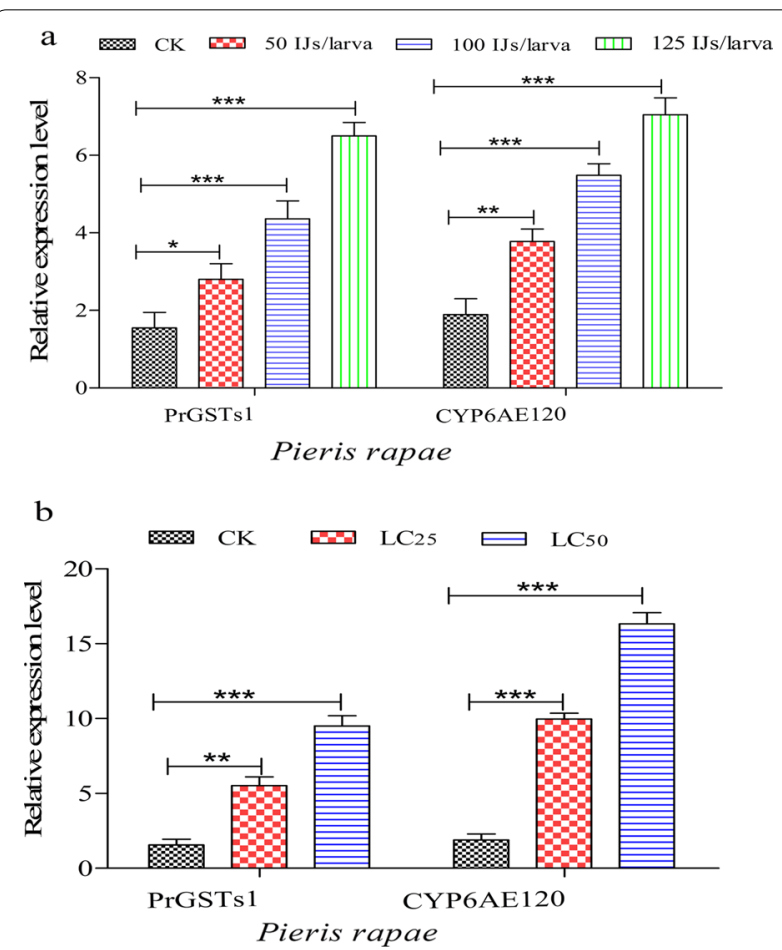

Fig. 2 Relative expression levels of PrGSTs1 and CYP6AE120 in larvae exposed to three different concentrations $(50 \mathrm{lJs} / \mathrm{larva}, 100 \mathrm{IJs} / \mathrm{larva}$ and $125 \mathrm{IJs} /$ larva) of $\mathrm{H}$. bacteriophora (HP88) (a), $\mathrm{LC}_{25}$ and $\mathrm{LC}_{50}$ values of lambda-cyhalothrin (b). The transcriptional level of each gene in H. bacteriophora or lambda-cyhalothrin-treated individuals was normalized relative to that in acetone-treated (control) individuals. ${ }^{*} P<0.05$ indicated the relationship between CK (control) and other treatment (Tukey's post hoc test, $p<0.05$ )

\section{Discussion}

Entomopathogenic nematodes (EPNs) are lethal insect parasites that live in soil and belong to the families Steinernematidae and Heterorhabditidae in the Phylum Nematoda. They have proven to be the most efficient biological control organisms for soil and above-ground pests (Laznik et al. 2010). In the present study, H. bacteriophora (HP88) was the most effective biological control nematode species, followed by $H$. bacteriophora (Ar-4). $S$. carpocapsae (All strain) at different concentrations was less effective, while $S$. feltiae was the least successful one on 3rd and 4th larval instars of $P$. rapae. The $\mathrm{LT}_{50}$ value of $H$. bacteriophora (HP88) demonstrated that it was the most virulent nematode 3 days post-treatment, followed by H. bacteriophora (Ar-4), then S. carpocapsae (All strain). S. feltiae was the least virulent nematode according to its $\mathrm{LT}_{50}$ value on $3 \mathrm{rd}$ and 4 th instars $P$. rapae larvae. Reda et al. (2018) reported that the cumulative mortality of $P$. rapae increased as a result of $S$. carpocapsae infection. Moreover, S. carpocapsae and S. feltiae are known to have a role in controlling the 4th instar of 
P. rapae larvae (Salem et al. 2007). In this respect, the authors found that the larvae of P. rapae and Agrotis ipsilon were very sensitive to the nematode and both insects died 3-5 days after inoculation. Furthermore, Saleh (1995) found in a bioassay test that the Heterorhabditis tayserae nematode at concentrations of 5-100 IJs/larva of P. rapae induced $30-100 \%$ and $55-100 \%$ mortality within 24 and 48 h., respectively. Additionally, larvae of $P$. rapae infected with $S$. feltiae exhibited mortality 3 days after exposure ranging from 75 to $97.5 \%$ (Wu and Chow 1989). S. carpocapsae (All strain) and S. carpocapsae S2 were more virulent to the 2 nd larval instar of $P$. rapae than the 5th instar, but Hemidesmus indicus SAA2 and H. bacteriophora HP88 were more virulent heterorhabditids to the 5 th larval instar than the 2nd one (Salem et al. 2007). A similar result was noted by Belair et al. (2003) who demonstrated a significant relationship between the mortality of $P$. rapae and the time of their exposure to IJs.

Obtained data indicated that the $\mathrm{LC}_{25}$ and $\mathrm{LC}_{50}$ values of lambda-cyhalothrin, emamectin benzoate, and indoxacarb all reduced the numbers of 3rd and 4th larval instars of $P$. rapae. Nevertheless, lambda-cyhalothrin is a better treatment than the other pesticides. This may be due to its different of mode of action from the other tested pesticides. Toxicological interactions of insecticides with EPNs can cause the final toxicity of the mixture to decrease (antagonism), can add to toxicity (additive) and increase toxicity (synergism or potentiation) with some chemicals (Capinera 2008). The findings revealed the additive effect was observed between EPN species with $\mathrm{LC}_{25}$ and $\mathrm{LC}_{50}$ values of lambda-cyhalothrin and emamectin benzoate on the mortality of 3rd instar $P$. rapae mortality, except that lambda-cyhalothrin at $\mathrm{LC}_{50}$ with $H$. bacteriophora (Ar-4) exhibited an antagonistic effect 3 days post-treatment. An antagonistic effect was observed with $\mathrm{LC}_{50}$ of indoxacarb. An additive effect was observed with all tested insecticides at $\mathrm{LC}_{25}$ with EPN species, except for lambda-cyhalothrin with $S$. carpocapsae (All strain) and indoxacarb with $H$. bacteriophora (Ar-4) that showed potentiation effects on 4th larval instar mortality of $P$. rapae 3 days post-treatment. The interaction of the tested pesticides at $\mathrm{LC}_{50}$ with EPNs showed an additive effect on 4th larval instar mortality of P. rapae 3 days post-treatment, excluding the interaction of $S$. feltiae with tested insecticides at $\mathrm{LC}_{50}$ which exhibited an antagonistic effect. This result may be because some pesticides have different effects on nematodes due to the differentiation of nematodes and insect physiology and feeding patterns (Özdemir et al. 2020). The pattern of interaction was dependent on nematode species (Zhang et al. 2020). This result confirms the work of Fetoh et al. (2009) who mentioned that the mortality numbers of $A$. ipsilon increased when treated with a mixture of $S$. carpocapsae and indoxacarb. In addition, S. carpocapsae (All strain) in combination with $\mathrm{LC}_{50}$ of indoxacarb was much more effective against Tuta absoluta than by using it alone (Sabry et al. 2016). Combined applications of insecticides and EPNs (H. bacteriophora and S. feltiae) allow for a reduction in the rates of chemical pesticide and EPNs usage (Kary et al. 2021). There is compatibility of $S$. feltiae with pesticides to reduce the number of T. absoluta (Garcia-del-Pino et al. 2013). Additionally, an antagonistic effect of S. feltiae with dichlorvos, abamectin, and azadirachtin was detected when the nematodes were applied immediately after insecticide application (Amizadeh et al. 2019). Another study reported that oxamyl increased S. carpocapsae efficacy against Agrotis segetum synergistically (Amin 1999). Vashisth et al. (2013) reported that combinations of chemical agent with nematodes resulted in synergistic levels of insect mortality.

In this study, lambda-cyhalothrin caused significant changes in expression of CYP6AE120 and PrGSTs1 compared to $H$. bacteriophora (HP88), suggesting that there might be a different mode of action between pesticides and EPNs. In addition, many employing functional expression assays have found that resistance to pesticides can be achieved through elevated expression of pesticide-metabolizing enzymes such as members of cytochrome P450 and glutathione-S-transferases groups (Chung et al. 2007). Liu et al. (2018) reported that 4 genes (PrGSTe3, PrGSTs1, PrGSTs2, and PrGSTs4) belonging to glutathione-S-tranferase were expressed predominantly in different tissues of $P$. rapae in response to abamectin. Furthermore, CYP6AE120 exhibited an up-regulated expression level in $P$. rapae when exposed to chlorantraniliprole. Therefore, these genes are potential candidates involved in the detoxification of the tested insecticides.

\section{Conclusions}

This study indicated that all the EPNs induced high mortality in the $P$. rapae larvae and gave promising results. Although heterorhabditid species appeared to be more virulent than steinernematid ones, generally, there were statistically insignificant differences between the EPN species. The local species $H$. bacteriophora (Ar-4 strain and the imported species, H. bacteriophora (HP88 strain) achieved a high mortality 3 days post-treatment of the 3rd and 4th larval instars of $P$. rapae when combined with the $\mathrm{LC}_{25}$ and $\mathrm{LC}_{50}$ values of insecticides (lambda-cyhalothrin, emamectin benzoate, and indoxacarb) using an appropriate concentration (50 IJs/larva). Hence, H. bacteriophora (HP88 strain) and H. bacteriophora (Ar-4 strain) have the potential to be used as a biocontrol agent for the integrated management of valued vegetable crops that 
are infested with $P$. rapae under protected cultivation. Moreover, lambda-cyhalothrin significantly up-regulated the expression of CYP6AE120 and PrGSTs1 compared to $H$. bacteriophora (HP88). This study suggests that the preventive use of systemic insecticides applied on foliar parts of cabbage plants combined with applications of local and imported $H$. bacteriophora strains can be a successful approach for controlling $P$. rapae, while reducing the inappropriate overuse of insecticides.

\begin{abstract}
Abbreviations
EPNs: Entomopathogenic nematode; IPM: Integrated pest management; $P$. rapae: Pieris rape; S. carpocapsae: Steinernema carpocapsae; S. feltiae: Steinernema feltiae; H. bacteriophora: Heterorhabditis bacteriophora; H. bacteriophora: Heterorhabditis bacteriophora; $\mathrm{LC}_{25}$ : Quarter lethal concentration; $\mathrm{LC}_{50}$ : Half lethal concentration; $\mathrm{LT}_{50}$ : Half lethal time.
\end{abstract}

\section{Acknowledgements}

We gratefully acknowledge Dr. Ahmed Erfan, Assistant lecturer at Animal health institute, Dokki, Egypt for helping us in some experiments in our article.

\begin{abstract}
Authors' contributions
AAA designed and achieved the planning of the experiments and wrote the manuscript. AAA and RME carried out the experiments. AEA and RME have done the analysis of the data. AAA and ASH had done the sample collection for gene expression. RME and AEE helped in the planning of the experiment and critically revised the article. The authors read and approved the final manuscript.
\end{abstract}

\section{Funding}

None.

\section{Availability of data and materials}

The datasets used and/or analyzed during the current study are available from the corresponding author on reasonable request.

\section{Declarations}

Ethics approval and consent to participate

Not applicable.

\section{Consent for publication}

Not applicable.

\section{Competing interests}

The authors declare no competing interests.

\section{Author details}

${ }^{1}$ Plant Protection Department, Faculty of Agriculture, Zagazig University, Zagazig 44511, Egypt. ${ }^{2}$ Stored Product Pests Research Department, Plant Protection Research Institute, Agricultural Research Center, Sakha, Kafr El-Sheikh, Egypt. ${ }^{3}$ Department of Project Management and Sustainable Development, Arid Lands Cultivation Research Institute, City of Scientific Research and Technological Applications, New Borg El-Arab, Alexandria 21934, Egypt.

Received: 31 August 2021 Accepted: 6 December 2021

Published online: 15 December 2021

\section{References}

Amin B (1999) Integrated control of insect pests by Steinernema carpocapsae. Jurnal Agrista (Indonesia)

Amizadeh M, Hejazi MJ, Niknam G, Askari-Saryazdi G (2019) Interaction between the entomopathogenic nematode, Steinernema feltiae and selected chemical insecticides for management of the tomato leafminer, Tuta absoluta. Biocontrol 64:709-721

Bedding R, Akhurst R (1975) A simple technique for the detection of insect paristic rhabditid nematodes in soil. Nematologica 21:109-110

Belair G, Fournier Y, Dauphinais N (2003) Efficacy of steinernematid nematodes against three insect pests of crucifers in Quebec. J Nematol 35:259

Capinera $J \mathrm{~L}$ (2008) Encyclopedia of entomology. Springer, Berlin

Chung H, Bogwitz MR, McCart C, Andrianopoulos A, Ffrench-Constant $\mathrm{RH}$, Batterham P, Daborn PJ (2007) Cis-regulatory elements in the Accord retrotransposon result in tissue-specific expression of the Drosophila melanogaster insecticide resistance gene Cyp6g1. Genetics 175:1071-1077

Dara SK (2017) Entomopathogenic microorganisms: modes of action and role in IPM. UCANR e-J Entomol Biol

El-Ashry RM, Ramadan MM (2021) In vitro compatibility and combined efficacy of entomopathogenic nematodes with abamectin and imidacloprid against the white grub, pentodon bispinosus Kust. Egypt Acad J Biol Scie F. Toxicol Pest Control 13:95-114

El-Ashry R, Ali MA, Elsobki AE, Aioub AA (2021) Integrated management of Meloidogyne incognita on tomato using combinations of abamectin, Purpureocillium lilacinum, rhizobacteria, and botanicals compared with nematicide. Egypt J Biol Pest Control 31:1-10

Fantke P, Friedrich R, Jolliet O (2012) Health impact and damage cost assessment of pesticides in Europe. Environ Int 49:9-17

Fetoh BESA, Khaled AS, El-Nagar TF (2009) Combined effect of entomopathogenic nematodes and biopesticides to control the greasy cut worm, Agrotis ipsilion (Hufn.) in the strawberry fields. Egypt Acad J Biol Sci A Entomol 2:227-236

Finney DJ (1971) Probit analysis, 3rd edn. Cambridge University, London, p 333

Garcia-del-Pino F, Alabern X, Morton A (2013) Efficacy of soil treatments of entomopathogenic nematodes against the larvae, pupae and adults of Tuta absoluta and their interaction with the insecticides used against this insect. Biocontrol 58:723-731

Kary NE, Sanatipour Z, Mohammadi D, Koppenhöfer AM (2018) Developmental stage affects the interaction of Steinernema carpocapsae and abamectin for the control of Phthorimaea operculella (Lepidoptera, Gelechidae). Biol Control 122:18-23

Kary NE, Sanatipour Z, Mohammadi D, Dillon AB (2021) Combination effects of entomopathogenic nematodes, Heterorhabditis bacteriophora and Steinernema feltiae, with Abamectin on developmental stages of Phthorimaea operculella (Lepidoptera, Gelechiidae). Crop Prot 143:105543

Kaya H, Stock S (1997) Techniques in insect nematology. In "Manual of techniques in insect pathology"(LA Lacey, Ed.). Academic Press, London

Khan RR, Arshad M, Aslam A (2021) Additive interactions of some reduced-risk biocides and two entomopathogenic nematodes suggest implications for integrated control of Spodoptera litura (Lepidoptera: Noctuidae). Sci Rep 11:1-9

Kingsolver JG (2000) Feeding, growth, and the thermal environment of cabbage white caterpillars, Pieris rapae L. Physiol Biochem Zool 73:621-628

Laznik Ž, Trdan S (2014) The influence of insecticides on the viability of entomopathogenic nematodes (Rhabditida: Steinernematidae and Heterorhabditidae) under laboratory conditions. Pest Manag Sci 70(5):784789. https://doi.org/10.1002/ps.3614

Laznik Ž, Trdan S (2017) The influence of herbicides on the viability of entomopathogenic nematodes (Rhabditida: Steinernematidae and Heterorhabditidae). Int J Pest Manag 63:105-111

Laznik Ž, Tóth T, Lakatos T, Vidrih M, Trdan S (2010) Control of the Colorado potato beetle (Leptinotarsa decemlineata [Say]) on potato under field conditions: a comparison of the efficacy of foliar application of two strains of Steinernema feltiae (Filipjev) and spraying with thiametoxam. J Plant Dis Prot 117:129-135

Liu S, Zhang YX, Wang WL, Cao Y, Li S, Zhang BX, Li SG (2018) Identification of putative cytochrome P450 monooxygenase genes from the small white butterfly, Pieris rapae (Lepidoptera: Pieridae), and their response to insecticides. Arch Insect Biochem Physiol 98:e21455

Liu S, Zhang Y-X, Wang W-L, Zhang B-X, Li S-G (2017) Identification and characterisation of seventeen glutathione S-transferase genes from the cabbage white butterfly Pieris rapae. Pestic Biochem Physiol 143:102-110. https://doi.org/10.1016/j.pestbp.2017.09.001 
Mansour N, Eldefrawi M, Toppozada A, Zeid M (1966) Toxicological studies on the Egyptian cotton leaf worm, Prodenia litura. VI. Potentiation and antagonism of organophosphorus and carbamate insecticides. J Econ Entomol 59:307-311

Özdemir E, Inak E, Evlice E, Laznik Z (2020) Compatibility of entomopathogenic nematodes with pesticides registered in vegetable crops under laboratory conditions. J Plant Dis Prot 127:529-535

Qie X, Lu W, Aioub AA, LiY, Wu W, Hu Z (2020) Insight into the detoxification of haedoxan $A$ and the synergistic effects of phrymarolin I against Mythimna separata. Ind Crops Prod 158:112967

Reda E, Sallam A, Ibrahim H, Eid S (2018) Efficacy of Entomopathogenic Nematode, Steinernema carpocapsae and its Interaction with Beauveria bassiana against Pieris rapae L. (Lepidoptera: Pieridae). J Plant Prot Pathol 9:795-798

Richer DL (1987) Synergism — a patent view. Pestic Sci 19:309-315

Robertson JL, Jones MM, Olguin E, Alberts B (2017) Bioassays with arthropods. CRC Press

Sabry K, Metwallya H, Abolmaatyb S (2016) Compatibility and efficacy of entomopathogenic nematode, Steinernema carpocapsae all alone and in combination with some insecticides against Tuta absoluta. Pharm Lett 8:311-315

Saleh M (1995) Efficiency of the Egyptian entomopathogenic nematode, Heterorhabditis taysearae in controlling the cabbage-worm, Pieris rapae (L.)(Lepidoptera: Pieridae). Egypt J Biol Pest Control 5:99-112

Salem S, Abdel-Rahman H, Zebitz C, Saleh M, Ali Fl, El-Kholy M (2007) Evaluation of entomopathogenic nematodes in controlling some cabbage pests. J Appl Sci Res 3:323-328

Vashisth S, Chandel YS, Sharma PK (2013) Entomopathogenic nematodes - A review. Agric Rev 34(3):163. https://doi.org/10.5958/j.0976-0741.34.3.001

Wu H, Chow Y (1989) Susceptibility of pieris-rapae-crucivora (lepidoptera, Pieridae) to the imported entomogenous nematode steinernema-feltiae. Bull Inst Zool Acad Sin 28:237-244

Xiang M, Zhang X, Deng Y, Li Y, Yu J, Zhu J, Huang X, Zhou J, Liao H (2018) Comparative transcriptome analysis provides insights of anti-insect molecular mechanism of Cassia obtusifolia trypsin inhibitor against Pieris rapae. Arch Insect Biochem Physiol 97:e21427

Yuan JS, Reed A, Chen F, Stewart CN (2006) Statistical analysis of real-time PCR data. BMC Bioinf 7:1-12

Zhang Y, Li S, Li H, Wang R, Zhang K-Q, Xu J (2020) Fungi-nematode interactions: diversity, ecology, and biocontrol prospects in agriculture. J Fungi $6: 206$

\section{Publisher's Note}

Springer Nature remains neutral with regard to jurisdictional claims in published maps and institutional affiliations.

\section{Submit your manuscript to a SpringerOpen ${ }^{\circ}$ journal and benefit from:}

- Convenient online submission

- Rigorous peer review

- Open access: articles freely available online

- High visibility within the field

- Retaining the copyright to your article 